\title{
Economic and sociocultural poverty in drug \\ abuse: from individual to sociopolitical \\ responsibility
}

\section{Pobreza econômica e sociocultural no abuso de drogas: da responsabilidade individual à sociopolítica}

\author{
Ana Erika Oliveira Galvão ${ }^{a}$ \\ aniversidade Estadual do Ceará. Faculdade de Educação, \\ Ciências e Letras do Sertão Central. Quixadá, CE, Brasil. \\ E-mail: anaerikagalvao®gmail.com \\ Luísa Saavedrab

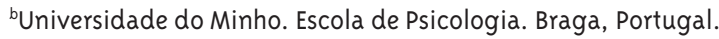 \\ E-mail: Isaavedraळpsi.uminho.pt \\ Miguel Cameira ${ }^{\mathrm{C}}$ \\ 'Universidade do Porto. Faculdade de Psicologia e de Ciências \\ da Educação. Porto, Portugal. \\ E-mail: cameira®fpce.up.pt
}

\section{Correspondência}

Ana Erika Oliveira Galvão

Rua Paula Ney, 520/40IB, Aldeota. Fortaleza, CE, Brasil. CEP 60140-200.

\section{Abstract}

Research on drug abuse has often ignored users' own opinions and perceptions about their addiction. In this study, we wanted to hear their voice on the reasons and motives why they engaged in drug abuse, and on the consequences this behavior had on their lives. Data were collected in Portugal from interviews with fifteen people under treatment for addictive behavior relative to alcohol and illegal drugs. The interviews were analyzed through Thematic Analysis and revealed the existence of several structural factors impacting on the lives of the participants, namely, gender discrimination, poor schooling, socioeconomic marginalization and exclusion associated to insufficient and inadequate public policies. The action of more symbolic structural factors - for instance, their widespread beliefs on drug addiction as a result of free will - through its internalization by families, friends and by addicts themselves, became visible in interviewees' narratives, in which the rejection by close ones, as well as their own feelings of guilt, sadness and self-disapproval, are prominent features. As a conclusion, we call attention to the need for an integrated public policy in the educational, health and justice areas, and the implementation of awareness-raising actions aimed at the general public, in order to attenuate the impact of structural factors on the lives of current and potential drug addicts.

Keywords: Drug Addiction; Structural Violence; Social Suffering. 


\section{Resumo}

A pesquisa sobre o abuso de drogas tem frequentemente ignorado as opiniões dos próprios usuários e as suas perceções sobre a sua dependência. Neste estudo, quisemos ouvir a sua voz sobre as razões e os motivos por que se engajaram no abuso de drogas e sobre as consequências que este comportamento teve nas suas vidas. Os dados foram coletados em Portugal a partir de entrevistas com quinze pessoas sob tratamento para comportamento aditivo em relação a álcool e drogas ilegais. As entrevistas foram analisadas através de análise temática e revelaram a existência de diversos fatores estruturais impactando na vida dos participantes, ou seja, discriminação de gênero, escolaridade baixa, marginalização socioeconômica e exclusão associados a políticas públicas insuficientes e inadequadas. A ação de fatores estruturais mais simbólicos - por exemplo, suas crenças generalizadas na toxicodependência como resultado do livre-arbítrio - através de sua interiorização pelas famílias, amigos e pelos viciados em si, tornou-se visível nas narrativas dos entrevistados, em que a rejeição pelos próximos, além de seus próprios sentimentos de culpa, tristeza e autodesaprovação, são características proeminentes. Como conclusão, chamamos atenção para a necessidade de uma política pública integrada nas áreas de educação, saúde e justiça, e a implementação de ações de sensibilização visando o público em geral, a fim de atenuar o impacto dos fatores estruturais sobre a vida dos atuais e potenciais viciados em drogas.

Palavras-chave: Toxicodependência; Violência Estrutural; Sofrimento Social.

\section{Introduction}

Drug abuse is a highly prevalent, complex individual behavior, with implications to several administrative, juridical and public policy areas, such as Healthcare, Justice and Employment. For instance, drug addicts are often incapable of maintaining a regular job or source of income, leading to various forms of so-called 'deviant' behavior, such as robbery and swindle, so they can obtain their daily dose. Continued consumption of drugs and/or alcohol and the associated disregard for other essential needs also entails the progressive deterioration of the addicts' health. For these reasons, drug abuse is particularly disruptive for families and, often, communities. These features, together with the generalized belief of the intentionality of drug abuse, have led to the development of highly negative societal attitudes and beliefs in regard to drug addicts, added to their already problematical lives.

In this study, we attempted to analyze some of these issues based on the drug addicts' own narratives. Indeed, little attention has been given to drug addicts' perceptions of the reasons for their abusive consumption, and the consequences this behavior had on their lives. As pointed out by Marsh and Shevell (1983), the addicts' voice and point of view should be a primary consideration in the planning of public policies and treatment programs. Thus, in the present paper, we provide drug addicts' own views on the reasons and causes that led them to drug consumption, and the repercussions that drug abuse had on their lives. As shown below, participants' narratives occasionally reveal their awareness of socio-structural forces, for instance, economic factors, impacting on their lives; on the other hand, they seem to have internalized the widespread negative stereotypes and beliefs about addiction that result from their assuming the entire responsibility for their situation. Since in scientific and layman discourses drug abuse is often regarded as an individual problem, having little to do with the social context in which it emerges (Chen; McElderr, 2007), in this paper, we reinstate the need for a shift of focus when addressing the drug abuse issue. 
We shall begin by briefly presenting some key concepts, stigma, structural violence and social suffering, created by authors, such as Ervin Goffman or Johan Galtung, to address similar problems based on their socio-structural dimensions. These are important tools for discussing our participants' narratives. When necessary, we introduce brief notes regarding the specificity of the Portuguese context, relevant to a better understanding of the narratives.

\section{The stigmatization of drug addiction}

Throughout the $19^{\text {th }}$ century and beginning of the $2 \mathrm{O}^{\text {th }}$, people who abused drugs were consensually viewed as solely responsible for their immoral behavior, and considered 'moral failures' or 'bad persons' (Harding, 1986). In contrast, the current medical view sustains that 'Substance Use Disorders' derive from damages to inhibitory mechanisms of the brain (APA, 2014) and that drug use impairs the brain's capacity to produce substances that give us control of our will. Additionally, genetic factors may have a role in the onset of the disease (Sloboda; Glantz; Tarter, 2012). However, this medical view has not been able to dismiss the widely shared belief that addicts are fully accountable for their condition, i.e., that they choose to abuse drugs. This collective belief, also internalized by drug addicts and close ones, triggers feelings of guilt and shame, and promotes rejection by families and stigmatization in communities and institutions (Corrigan; Kuwabara; O'Shaughnessy, 2009; Earnshaw; Smith; Copenhaver, 2013).

Stigma is a fundamental concept in the discussion of drug addiction. This notion was introduced by Goffman (1963) who defined it as a "deeply discrediting" attribute which reduces its carrier "from a whole and usual person to a tainted, discounted one" (p. 3). The author provides examples of addiction and alcoholism together with mental disorder, imprisonment, and homosexuality (Goffman, 1963, p. 14). However, as other authors have noted, the attribute of drug addiction is so strong that it "obscures all others" (Lloyd, 2013, p. 9). When other socially disadvantageous attributes are present, such as being black, female, having Hepatitis C, HIV or some mental disorder, drug addiction remains the most salient aspect (Corrigan; Kuwabara; O'Shaughnessy, 2009; Lloyd, 2013).

In addition to these personal and social hardships, and because many drugs were formally criminalized, drug addicts started to face the increasing threat of police persecution and imprisonment. In Portugal, drug use was criminalized in 1970, but, in 1983 , legislators established a clear difference between drug trafficking and drug consumption, so that the punishment for the latter was merely symbolic, relatively light (Agra, 2009). More recently, Law 30/2000 (Portugal, 2000) decriminalized all illicit drug possession and consumption up to a quantity corresponding to the average individual consumption during a 10-day period. Consequently, instead of being arrested, drug users are referred to the local Commission for the Dissuasion of Drug Use, who determines the respective administrative sanction (Agra, 2009). Nonetheless, the possession of illegal substances (in trafficking amounts) continues to represent a substantial portion of police indictments - $18.9 \%$ (DGRSP, 2016) since many consumers resort to trafficking in order to pay for their daily doses (not to mention the detentions for crimes against property that are committed by drug users, with the same goal; which, according to DGRSP, 2016, accounts for $27.7 \%$ of all detentions). This situation leads to the third problem: the strong relationship between drug consumption and economic destitution.

Taking into account the life stories of these participants, with crossed paths of addiction, crime, and economic and sociocultural poverty, we believe that the concepts of structural violence and social suffering are particularly useful for the analysis and discussion of the obtained data. These concepts have been used to interpret and discuss innumerous forms of social discrimination and exclusion (Galtung, 1969; Kleinman; Das; Lock, 1997), but, to our knowledge, they have never been applied to the problem of substance abuse.

\section{Structural violence and social suffering: causes and consequences of addiction}

Structural violence can be seen both as the cause and consequence of drug addiction. As a cause, it can 
be identified in the destitute backgrounds of many consumers, and the social inequality and injustice they have continuously experienced throughout their development, prior to becoming addicted. As a consequence, structural violence is visible in the way drug addicts are treated by the justice system, health services, and by their families and communities, after being socially and institutionally labelled.

The notion of structural violence, introduced by Galtung (1969), is important for drug addiction issues because it emphasizes the impact of differences in power among different social groups to individuals' lives, and that this power differential results in a persistent lack of opportunities for those belonging to the most vulnerable groups. Structural violence is thus characterized by persistence, and can act either manifestly or latently, intentionally or unintentionally, and physically or psychologically. It undermines basic needs, including survival, welfare, identity and freedom (Galtung, 1969). As we will argue, for many of our interviewees, both poverty and gender discrimination were important causes for becoming addicted to drugs.

The notion of social suffering, a political concept that designates the subjective consequences of all forms of social injustice (Kleinman; Das; Lock, 1997), is also an important tool in the analysis of drug addiction. Moreover, it entails the duty of exposing hidden responsibilities, which, we believe, is particularly relevant in the case of drug addiction. Specifically, the effective comprehension of the subjective aspects of social suffering allows the identification of its socio-structural component and, conversely, to see that this component is indispensable in the understanding of its subjective aspects (Kleinman; Das; Lock, 1997). Indeed, when one relates to drug addicts' inner feelings, and understands the nature of the problems associated with their addiction, one can see the role of the social structure, and its various forms of inequality and injustice, in their suffering.

The internalization of social suffering, and the acceptance of its causes as normal facts, lead to marginalized and vulnerable minorities that, even unintentionally, become complicit in their own subordination (Kleinman; Das; Lock, 1997). Furthermore, such internalization has the perverse consequence of perpetuating what Kleinman, Das, and Lock (1997) called the "cycle of risky behaviors" among members of these minorities. Risky behaviors, such as 'deviant' acts and drug addiction, translate into cycles of daily violence that take place in the public space, but resonate in the subjective and individual domains in the form of personal deficits, psychological damage and the sense of having no control.

The above-described notions guided the questions we formulated for the interviews, as well as the analysis of the accounts. Specifically, we focused on participants' perceptions on the role of structural violence (including gender issues, poor socio-economic conditions and negligent public policies) on the onset of drug abuse. We also gave particular attention to the subjective consequences of the internalized beliefs that drug addiction is an individual responsibility and a choice. As noticed by Corrigan, Kuwabara and O'Shaughnessy (2009) or Lloyd (2010, 2013), these beliefs, which in fact rest on a strongly moralist view of drugs, fits the case of drug addiction better than other physical and mental diseases.

\section{Method}

\section{Interviews and data analysis}

Three main questions guided the semi-structured interviews. The first one dealt with chemical dependence history, the onset of excessive consumption and the reasons for this consumption. This allowed us to understand the perceived reasons for drug use, whether personal, sociocultural, economic or political, and the ideas that regulate these perceptions. The second sought to understand family relationships in the context of drug addiction. Finally, we tried to understand the reasons that led the participants to seek institutional treatment and how they felt about it.

We analyzed the interviews using Braun and Clarke's (2006) Thematic Analysis method. After carefully reading all the transcripts, we selected and organized the more salient excerpts according to their latent meanings, similarities and differences. Finally, we chose the excerpts that best illustrated the identified themes. 


\section{Procedures}

The interviews were conducted in a therapeutic community in the North of Portugal, where users reside during the treatment. The institution is funded by the Social Security Institute and the Agency of Intervention on Addictions and Dependences. Even so, users are financially responsible for their personal expenses with tobacco and hygiene products. We chose this institution due to the renowned quality of their work, as well as the receptiveness of its board to collaborate with the research. To recruit participants, we asked the board to make a brief survey of users' interest to participate. We excluded candidates with cognitive impairment that could compromise the understanding of the interview. Fifteen users met the inclusion criteria and volunteered for the interview after being informed of its goal. The interviews took place in the community and were recorded under informed consent.

The analysis of the interviews and their discussion, which will be presented simultaneously, were guided by the two main themes previously identified in the transcripts:
(1) Reasons for Substance Abuse: From Psychological Difficulties to Structural Inequalities, subdivided into two subthemes: (a) Gender Discrimination and its Relationship with Poverty and (b) Poverty, Marginalization and Economic Crises;

(2) Social Suffering and Substance Abuse: From Family to Institutional Violence, including two subthemes: (a) Violence of Family and (b) Coercive Treatments.

\section{Results and Discussion}

\section{Participants' characteristics}

The 15 participants (described in Table 1 ) belonged to both sexes ( $60 \%$ male), had diverse ages (Mean $=24$ years old, including a 55 years old) and various levels of education ( $47 \%$ had 12 or more years of schooling), reflecting the fact that addiction crosses all social and economic levels. All participants were under treatment for abuse of legal (53\%) or illegal drugs (47\%). They were heterogeneous in terms of age and type of drug used (legal or illegal), thus contributing to increase the diversity of experiences, meanings and realities under analysis (Braun; Clarke, 2006).

\section{Table I - Participants' sociodemographic characteristics and explicit motives for addiction}

\begin{tabular}{|c|c|c|c|c|c|c|c|}
\hline $\begin{array}{l}\text { Fictitious } \\
\text { Name }\end{array}$ & Sex & Age & $\begin{array}{l}\text { Years of } \\
\text { Schooling }\end{array}$ & $\begin{array}{l}\text { Substance } \\
\text { status }\end{array}$ & $\begin{array}{l}\text { Age of } \\
\text { Onset }\end{array}$ & $\begin{array}{l}\text { Coercive } \\
\text { Treatment }\end{array}$ & $\begin{array}{l}\text { Motives for } \\
\text { Addiction }\end{array}$ \\
\hline David & M & 35 & 4 & Illegal & 18 & Y & $\begin{array}{c}\text { Friends in a marginalized } \\
\text { environment }\end{array}$ \\
\hline Harry & M & 43 & 9 & Illegal & 18 & Y & Military service \\
\hline Donald & M & 32 & 12 & Illegal & 14 & Y & $\begin{array}{c}\text { Friends in a marginalized } \\
\text { environment }\end{array}$ \\
\hline Anne & $\mathrm{F}$ & 45 & 4 & Alcohol & 35 & $\mathrm{~N}$ & Sexual harassment and IPV \\
\hline Louise & $\mathrm{F}$ & 37 & 9 & Alcohol & 27 & Y & $\begin{array}{c}\text { Depression followed by } \\
\text { divorce }\end{array}$ \\
\hline Diane & $\mathrm{F}$ & 47 & $\begin{array}{c}\text { Higher } \\
\text { Education }\end{array}$ & Alcohol & 20 & $\mathrm{~N}$ & Death of a boyfriend \\
\hline Daniel & M & 63 & 12 & Alcohol & 55 & $\mathrm{~N}$ & $\begin{array}{c}\text { Divorce and economic } \\
\text { problems }\end{array}$ \\
\hline Peter & M & 22 & $\begin{array}{l}\text { Higher } \\
\text { education }\end{array}$ & Illegal & 13 & $\mathrm{~N}$ & $\begin{array}{l}\text { Family problems and } \\
\text { personal insecurities }\end{array}$ \\
\hline
\end{tabular}


Table I - Continuation

\begin{tabular}{|c|c|c|c|c|c|c|c|}
\hline $\begin{array}{l}\text { Fictitious } \\
\text { Name }\end{array}$ & Sex & Age & $\begin{array}{l}\text { Years of } \\
\text { Schooling }\end{array}$ & $\begin{array}{l}\text { Substance } \\
\text { status }\end{array}$ & $\begin{array}{l}\text { Age of } \\
\text { Onset }\end{array}$ & $\begin{array}{l}\text { Coercive } \\
\text { Treatment }\end{array}$ & $\begin{array}{l}\text { Motives for } \\
\text { Addiction }\end{array}$ \\
\hline Rose & $\mathrm{F}$ & 46 & 4 & Alcohol & 19 & Y & $\begin{array}{l}\text { Family history of } \\
\text { alcoholism }\end{array}$ \\
\hline Paul & M & 23 & $\begin{array}{c}\text { Incomplete } \\
\text { higher } \\
\text { education }\end{array}$ & Illegal & 15 & $\mathrm{~N}$ & Friends and loneliness \\
\hline Eric & M & 27 & 12 & Illegal & 21 & N & $\begin{array}{l}\text { Friends and } \\
\text { unemployment }\end{array}$ \\
\hline Richard & M & 43 & II & Illegal & 16 & $\mathrm{~N}$ & $\begin{array}{l}\text { Pleasure from drug effects } \\
\text { and social disinhibition }\end{array}$ \\
\hline Agnes & $\mathrm{F}$ & 48 & 12 & Alcohol & 47 & $\mathrm{~N}$ & $\begin{array}{l}\text { Sexual harassment and } \\
\text { subsequent depression }\end{array}$ \\
\hline John & M & 33 & 9 & Illegal & 15 & $\mathrm{~N}$ & $\begin{array}{c}\text { Friends in a marginalized } \\
\text { social environment }\end{array}$ \\
\hline Emily & $\mathrm{F}$ & 53 & 4 & Alcohol & 27 & Y & $\begin{array}{l}\text { IPV and sensibility to } \\
\text { alcohol }\end{array}$ \\
\hline
\end{tabular}

Reasons for substance abuse: from psychological difficulties to structural inequalities

All participants were able to identify clear reasons for their addictive behaviors, invoking either personal or contextual forces as the main factors. Three participants mentioned that addiction had been a problem in their families, suggesting the existence of hereditary factors.

In Table 2, we can see that the invoked reasons are generally multiple, except in four cases, where personal issues appear as the sole cause for the onset of abusive consumption. For Paul, whose parents lived abroad while he stayed with other relatives in unstable conditions, these personal issues included familial isolation; for Dianne, it was the death of her boyfriend in a road accident that led her to drinking. (Notably, these participants have a higher educational level than the majority.) In all other cases, the invoked reasons are described as external forces emanating from the social structure. As described above, these forces act upon people's lives, invisibly but persistently (Galtung, 1969), ultimately producing dramatic effects in basic areas. This is the case of gender discrimination, by itself or associated with poverty, and social marginalization due to long-term poverty, or to sudden personal insolvency following a major economic recession.

Table 2 - Reasons invoked for consumption

\begin{tabular}{|c|c|c|c|c|}
\hline & Marginalization & Personal Problems & $\begin{array}{c}\text { Gender } \\
\text { discrimination }\end{array}$ & Economic crises \\
\hline Poverty & David, Donald, John & Louise & Anne, Rose, Emily & Eric \\
\hline Personal Problems & - & $\begin{array}{l}\text { Harry, Diane, Peter, } \\
\text { Paul, Richard }\end{array}$ & - & Daniel \\
\hline $\begin{array}{l}\text { Gender } \\
\text { discrimination }\end{array}$ & - & - & Agnes & - \\
\hline
\end{tabular}




\section{Gender discrimination and its relationship with poverty}

Like their male counterparts, most of our female participants were raised from disadvantageous social, educational and economic backgrounds. However, as their narratives revealed, many have experienced the harmful effects of traditional and oppressive gender norms, frequently including incidents of sexual harassment and intimate partner violence (IPV). According to Crenshaw (1989), intersected forms of oppression have a multiplicative, rather than additive, effect; in other words, each condition significantly aggravates the others. First, women who abuse alcohol (like all our female participants) are seen as failures and a threat to traditional feminine roles and characteristics (Ettore, 2015). The shame associated with not fulfilling norms of femininity is evident in the fact that five of our six female participants consumed alcohol only in secret: that's the way it was, I drank in secret. I did not drink in front of people. People saw me and thought I was normal, because I was not falling to the floor (Louise). The fact that most female participants preferred drinking alone suggests that internalized forms of repression (Galtung, 1990), or, in their case, traditional gender norms, have led them to isolate themselves from others or, in other words, self-marginalize.

Except for my son and my mother, no one has ever seen me in an altered state, as a drunkard, ever! When my husband was there, I did not drink. He knew that I drank [only] because my son told him; him and my mother. At that time, when he was there for three or four days, I did not drink. Never in a café, on the street, I have never drank anywhere other than at home. (Agnes)

Moreover, the literature suggests the existence of strong correlations between drug abuse and gender discrimination (Ro; Choi, 2010), as well as IPV - in addition to other psychopathological alterations (Jaquier; Flanagan; Sullivan, 2015). In Anne’s story, we can find most of these conditions: I started getting more into alcohol when I got a divorce and Then, I unfortunately found a partner who beat me... I had a finger broken, that's when I started drinking more. This participant had also been a victim of sexual harassment at work, after which she was fired (and was still unemployed at the time of the interview).

Another case shows how sexual harassment may involve threats, subordination or difficult obligations at work, creating a hostile work environment, which can eventually lead to alcoholism (Richman, 1999). Despite having optimal circumstances (12 years of schooling, no previous history of alcohol or other drug use, a secretarial job, and a happy marriage), sexual harassment by Agnes' employer ultimately led her to social isolation: He always insisted, he called me to his office. I always refused his assaults... and then he began to 'punish me'... mistreat me in front of my colleagues (Agnes). After this happened too many times, she asked for a sick leave, and, ever since, started spending most of her time alone at home. Finally, she became depressed and started to drink. Despite the absence of concurrent factors, such as poor educational or economic conditions, her disadvantage as a woman was sufficient to drive her to alcohol and isolation.

Sexual harassment at work may be seen as a manifestation of structural violence against women (since they are the most frequent victims), since male aggressors lean considerably on traditional norms to initiate their actions. Similarly, the incapacity of many women to confront the harasser's behavior is partly due to their own endorsement of such norms, due to the previously mentioned concept of internalization of oppression (Galtung, 1990). Agnes' case thus provides the example of how addiction, in this instance alcoholism, may be a way of obtaining relief from issues caused by socio-structural factors, namely, gender discrimination in the form of patriarchal power (Jacobs, 2016).

\section{Poverty, marginalization and economic crises}

This subtheme stresses the role of poverty, poor schooling, and marginalized social neighborhoods complex processes of healthcare and disease. The role of the recent Portuguese economic crisis on the increase of drug and alcohol consumptions is also an important topic of this subtheme.

In Daniel's case, we find a direct relationship between drug abuse and the major economic crisis that hit Portugal in 2008. The negative effects of this crisis were intensified after 2011, when 
the Troika imposed several austerity measures aimed at recovering the country's economy. Among other effects, austerity measures provoked "the dismantling of the Social State, the privatization of public goods, the individualization of social risks and the commodification of social life" (Soeiro, 2014, p.10), resulting in higher taxes, lower wages and increasing unemployment rates (Ferreira, 2011). This situation had dramatic effects on public health, particularly mental health (loss of self-esteem, anxiety, depression), increasing the prevalence of risky behaviors, such as drugs and alcohol abuse.

Daniel, a middle-aged participant with a long story of drugs and alcohol abuse, attributes the cause of his current relapse to alcoholism to his divorce, which happened at the beginning of the great economic crisis:

I think it has to do with money. I had a buck, and the money disappeared. Then, there was the crisis, too. I was receiving an unemployment wage... Until then, I never worried about money, but then I started to. I closed myself off at home and started to drink... It was very hard for me to stop working... at first, it was a tremendous shock. Work began to decline even abroad, [and] I had no work in Portugal. (Daniel)

Richard also emphasizes the impact of the economic crisis:

I left a community and I went to live alone, but I only had my retirement income... and we were already in crisis, the country was already in crisis... and what I did was start getting my meals at St. Casa da Misericórdia, in Santarém... I used my pension to pay the room and then I had almost no money left.

Other narratives illustrate how the interaction of multiple forms of oppression (Crenshaw, 1989), such as poverty and marginalization, can act together to drive a person to abusive consumption. It is the case of both John and David.

John's narrative is an appropriate example of how the use of drugs, like any other behavior, may be learned from repeated exposition to models provided by one's environment, and become part of one's repertoire of responses to stressful events or inactivity (Marsh; Shevell, 1983): I was born in France, near Paris, in neighborhoods that were, well, 'dangerous,' or highly dangerous, one could say. When I left the house I would see people selling hashish and then I saw them smoking it. Family members also consumed.

Likewise, David invokes the role of peers and the subcultures of marginalized neighborhoods in his personal and social downfall, that is, his commitment to the life of drug trafficking and consumption that would take him to prison more than once:

When I started to consume, there were three or four [acquaintances] who already smoked... We went to have a drink, they stretched the silver foil [to burn the hashish], and they started to smoke and then they would ask me, 'do you want a try?'... Then, I lost my job, when I started getting high every day, and I began to work for them, for the person who sold it.

Finally, there is the interaction between poverty, low schooling and subcultures with obsolete traditions existing in rural environments, which are consensually considered strong predictors of alcohol abuse (UNODC, 2016):

I was probably seven years old, more or less. My mother worked in agriculture, on the land, and then we went to the fields to work with her. We ate fried codfish and people drank wine; they did not have water or juice... everyone drank wine. (Louise)

We will now center our analysis on the consequences of the stigma, attempting to expose the impact of widespread norms and beliefs on addicts' self-views, and on their associations with family, community and institutions.

\section{Social suffering and substance abuse: from familial to institutional violence}

\section{Familial violence}

Families with relatives suffering from substance abuse disorders, similar to those with chronic diseases or mental diseases, frequently resort to the healthcare 
system with complains of physical and psychological stress (e.g., Smith; Estefan, 2014). Families generally express frustration, grief (Incerti et al., 2015; Smith; Estefan, 2014), shame, guilt, distrust and the feeling that their relationships were 'permanently damaged' (Incerty, et al., 2015, p. 34). Concealing information from one another is also a usual practice among these families (Paula et al., 2014).

However, if families find drug addiction difficult to live with (e.g., Incerti; Henderson-Wilson; Dunn, 2015; Paula et al., 2014; Smith; Estefan, 2014), it is also true that most of them institute a form of payback, rejecting or making their drug addict relative feel guilty about his/her state. For instance, $31 \%$ of drug addicts inquired by Earnshaw, Smith and Copenhaver (2013) perceived negative feelings from their friends and relatives, especially parents.

In our participants' narratives, we could notice several types of negative feelings concerning a damaged relationship with their families, such as, sadness (especially when the family completely breaks ties), guilt, shame and personal devaluation over the disturbances caused within the family. For instance, David's narrative reveals sadness and shame when speaking of his family: I do not want to spend Christmas at home because I feel sorry for my mother's family... and the family friends. I feel bad about the family... the family crosses my path and I even hide from them! Rose also expressed sadness about her sister making her stay away from their mother, as if her mere presence and words could harm the mothers' health: My mother completed 84 years yesterday... but my sister does not allow me to talk to her. Finally, Donald remembered that, It was my first New Year's Eve away from my friends and away from the people that I love, for example, the mother of my children. These accounts show that family reactions to addiction had a devastating effect on participants, causing them shame and guilt, not to mention a sense of isolation and exclusion.

Inevitably, stigmatization also extends to the community. As Crisp, Cowan and Hart (2004) have remarked, alcoholics are generally seen as unpredictable and dangerous. Such widespread beliefs are translated into behaviors such as those described by our participants:
When I'm away from home, people mistreat me and my sister, but me more (Rose).

The neighbors and everyone look away, they do not greet me. (Eric)

I think that a person that is dependent on drugs or alcohol is seen in a different way... people and society in general soon reject them. (Peter)

They treat you differently... 'that person is drugged,' they say, and simply the word "drugged" says everything: that person is already a different person. (John)

The guilt deriving from the perception of having caused harm to their families (and in a lesser degree, to their communities) is present in all participants. This is due, at least in part, to the internalized discourse of personal responsibility (Crisp; Cowan; Hart, 2004). As we have already mentioned, much more than other kinds of disease, such as mental illness and HIV (Lloyd, 2013), drug and alcohol addiction are still viewed under a moral lens, and consumers are highly stigmatized. Even if recent medical approaches contend that drug abusers are not responsible for their disease, and that drug abuse should be treated like any other disease (e.g., Valkow, 2015), most of our participants expressed intense guilty, and feel completely responsible for their behaviors:

Yes, I feel guilty. It was the path that I chose. (John)

[My father] wanted me to go to college and everything, so I could focus on studying, without having to work to pay for it. He himself emigrated in order to pay formy studies, and I... I did not raise myself to the level of his effort. (Paul)

Yes, the day after [binge drinking] we always have guilt on our shoulders: 'I did this and that yesterday, and if I had not drank, I wouldn't have done this, and if I hadn't done this, I wouldn't have had this or that consequence.' It's the guilt, the first thing that weighs on me is guilt. And after that, the shame of seeing my image in the mirror and saying 
to myself, 'Look at what I've become! This is what I am!'. (Louise)

We can thus assume that participants have internalized the traditional view on addiction, including the idea of moral failure. If one compares the assertions made in respect to the first theme - where the strength of socio-structural factors is recognized - and their beliefs of personal responsibility - shown in respect to the second theme - one can easily imagine the latent confusion and conflict in their minds, and their lack of reliable information about their own condition.

These contradictory thoughts and feelings together with the repeated experience of rejection, the sense of having hurt their families, and the impact of the negative responses they receive - intensify emotional distress and the sense of personal devaluation. This condition certainly does not facilitate an overcoming of their addiction, as expressed by some participants:

And it's my fault... because I started to notice that I was getting addicted to these harder drugs, like cocaine and heroin, and I had the initiative to give my mother the credit card, so I would not blow the whole money away. But when I was in the mood to consume, I created a really bad atmosphere to get what I wanted. (Peter)

There was a moment when I walked out the door and I looked at myself in the mirror and said, 'I'm ashamed of myself'. (Harry)

It's the guilt, the first thing that weighed on me was guilt. I don't know if it was only in my head, but I think my daughter, my mother and my brothers were, by then, ashamed of me. They did not really demonstrate it, but I noticed something different about them. (Louise)

This subtheme shows that psychological violence from family members may lower the quality of people's interpersonal relationships, threatening their social support, both of which are important for mental health, treatment success (Earnshaw; Smith; Copenhaver, 2013; Incerty;
Henderson-Wilson; Dunn, 2015; Paula et al., 2014), and the reconstruction of self-identity (Best et al., 2016).

\section{Coercive treatments}

In the therapeutic community from which the data were collected, we found people who voluntarily submitted to the institution and others who were coerced by the Criminal Justice system. Three of our interviewees had been indicted for drug trafficking, and they were sent to this institution by the Court. Although drug consumption was decriminalized in 200o, drug trafficking is still punishable with imprisonment, from 4 to 12 years or from 1 to 5 years, depending on the types of substances involved. As such, they were doing time in prison while at the same time fulfilling the obligation of submitting to drug treatment. In other words, they were viewed as subjects who were "simultaneously treatable and punishable" (Lyons, 2014, p. 290). The overlap between the punitive model and the treatment model results in a "wider range of punishments and interventions in individuals' lives and behaviors" (Lyons, 2014, p. 290). This places them in an ambiguous position and perhaps explains their difficulty to find motivation for the treatment. This resistance may be seen, for example, in the testimony given by Harry, who was coerced by the court and his family: 'I'm not saying I didn't learn anything here; I did. I even like to be here and everything. But, I will say very sincerely, I think that I am now starting to feel blocked by the system; there are times when I get blocked.'

In addition to the three participants with a criminal history, three other participants were coerced to receive treatment for alcoholism. One of these participants had no social support, and the institution was her last chance: It was Social Security that told me to come here because I have nobody at home and could not be there by myself (Rose). Two participants submitted due to family pressures: for instance, Mother said that it was for my own good... and I said: whatever God wishes I'll go... (Emily). 
However, Emily, coerced by her family and by a physician, could hardly understand the treatment's dynamics:

The reason I came here was not work, but treatment. But they put me to work, so I have to work like everyone else! We are paying for treatment, and we do not have any money left at the end of the month. I think that a person who is undergoing treatment should be treated like they are in a hospital. If you're in a hospital, you don't have to work.

Besides the lack of motivation, coercion may trigger adverse feelings such as revolt:

At first, I came here against my will, I did not come here of my own free will... I will stay for one year. I may go to jail and then go home, but I will not be here for more than one year. (Harry)

When I go back home the first thing I'm going to do is go to the doctor and the psychologist and I'm going to get there and I'll just say: 'Look, I am very happy for what you two told me, you both should go there instead of me! I'm not a fool! I know!'. (Emily)

The above narratives expose the psychological violence experienced by these participants and their doubts on the efficacy of some treatments. This was, indeed, the only point at which the participants questioned public policies and services aimed at dealing with their problem. Throughout the interviews, they maintained an acritical or neutral attitude towards policies and institutions, perhaps due to the internalization of individual responsibility. In contrast, mandatory treatments are more and more questioned by researchers and analysts in terms of human rights and efficacy (Prendergast et al., 2009).

In this second theme, we could see how the stigma of drug addiction, including the attribution of personal responsibility and other moralizing discourses still in force, helps justify the state's lack of investment on this serious health problem. Such lack of investment inevitably leaves families and communities to deal with the problem themselves. As we have seen above, the state's omission, and the unpreparedness of families and communities to deal with the extreme problems associated with drug addiction, open a path to interpersonal violence, rejection, and isolation, causing even more suffering to the addict, with the resulting deterioration of his/her physical and mental health. The criminal system and treatment institutions, which should assume responsibility, also seem unprepared to deal with the issue's aggravation, and their inadequate measures and methods inflict additional suffering on addicts.

\section{Conclusions}

This paper allowed abusive drug consumers to talk about their perceived reasons for consumption, and to identify the role of socioeconomic and political factors on the onset of this problem. Our analysis revealed the confused and contradictory character of participants' discourse concerning the triggering and treatment of substance addiction; this discourse oscillated between personal and socio-structural responsibility, the former leading to feelings of guilt and shame. Considering the invisibility of structural violence, we are led to conclude that there is an urgent need for changes at the policy, judicial and institutional levels.

In the domain of public policies, the focus should be, as Pallamar (2013) advocates, on raising public awareness and education. According to the author (p. 372): "Education can help reduce misinformation and myths about users and addicts just as it has reduced myths about other mental illnesses" (Rüsch; Angermeyer; Corrigan, 2006). Addicts need to know that the responsibility for their behavior is not entirely theirs, in order to avoid guilt, shame and self-depreciation.

Secondly, we must remember that although Portugal has been following European directives on Gender Equality for approximately three decades, the fact is that Intimate Partner Violence, murder in particular, continues to reach dramatic numbers. Around 14 women are victims of violence per day (APAV, 2016), in a country with 10 million inhabitants, and the Gender Equality Index is below European Countries' average in all domains (EIGE, 2012). 
Public policies must also increase literacy and schooling, in order to attack unemployment, economic inequalities and, in general, all forms of social, cultural and economic destitution. In this sense, devising policies to tackle these deficiencies and strengthen the Welfare State would have a positive impact, reducing the problem and the prevalence of drug addiction. This issue is even more important as studies indicate that people of low socio-economic status living in deprived environments are more likely to be affected by drug and alcohol-related problems (Reis, 2013).

With the exception of Alcoholics Anonymous, we do not know of any other institution or service in Portugal that provides support to the relatives of drug addicts. This points to the need of improving assistance provided to families affected by drug addiction (Orford et al., 2012), in order to satisfy their demands for information, skills, resources and support (Orford, 2017; Paula et al., 2014).

Finally, we want to stress that only through a cooperative intervention from all public services educational, judicial and employment systems, as well as treatment institutions and familial assistance - can this social problem be effectively mitigated (Costa; Ronzani; Colugnati, 2017).

\section{References}

AGRA, C. Requiem pour la guerre à la drogue: l'expérimentation portuguaise de décriminalisation. Déviance et Société, Genève, v. 33, n. 1, p. 27-49, 2009.

APA - AMERICAN PSYCHIATRIC ASSOCIATION. Manual diagnóstico e estatístico de transtornos mentais: DSM V. Porto Alegre: Artmed, 2014.

APAV - ASSOCIAÇÃO PORTUGUESA DE APOIO À VÍTIMA. Estatísticas APAV: relatório anual 2016. Lisboa, 2016.

BEST, D. et al. Overcoming alcohol and other drug addiction as a process of social identity transition: the social identity model of recovery (SIMOR). Addiction Research and Theory, Abingdon, v. 24, n. 2, p. 111-123, 2016.
BRAUN, V.; CLARKE, V. Using thematic analysis in psychology. Qualitative Research in Psychology, London, v. 3, n. 2, p. 77-101, 2006.

CORRIGAN, P. W.; KUWABARA, S. A.;

O'SHAUGHNESSY, J. The public stigma of mental illness and drug addiction findings from a stratified random sample. Journal of Social Work, London, v. 9, n. 2, p. 139-147, 2009.

COSTA, P. H. A.; RONZANI, T. M.; COLUGNATI, F. A. B. "No papel é bonito, mas na prática...”: análise sobre a rede de atenção aos usuários de drogas nas políticas e instrumentos normativos da área. Saúde e Sociedade, São Paulo, v. 26, n. 3, p. 738750, 2017.

CRENSHAW, K. Demarginalizing the intersection of race and sex: a black feminist critique of antidiscrimination doctrine, feminist theory and antiracist politics. The University of Chicago Legal Forum, Chicago, v. 1, p. 139-167, 1989.

CRISP, A. H.; COWAN, L.; HART, D. The college's anti-stigma campaign. The Psychiatrist, London, v. 28, p. 133-136, 2004.

DGRSP - DIREÇÃO GERAL DE REINSERÇÃO E SERVIÇOS PRISIONAIS. Relatório Estatístico Anual 2016: assessoria técnica à tomada de decisão judicial e penas e medidas na comunidade nas áreas penal e tutelar educativa. 2016.

Disponível em: <https://bit.ly/2OeonoG>. Acesso em: 13 jan. 2017.

EARNSHAW, V.; SMITH, L.; COPENHAVER, $M$. Drug addiction stigma in the context of methadone maintenance therapy: an investigation into understudied sources of stigma. International Journal of Mental Health and Addiction, Basingstoke, v. 11, n. 1, p. 110-122, 2013.

EIGE - EUROPEAN INSTITUTE OF GENDER EQUALITY. Comparing in Gender Equality Index: 2012. Vilnius, 2012. Disponível em: <https://bit. ly/2xoLmPA>. Acesso em: 10 jun. 2017.

ETTORE, E. Embodied deviance, gender, and epistemologies of ignorance: re-visioning drugs use in a neurochemical, unjust world. Substance 
Use and Misuse, London, v. 5o, n. 6, p. 794-

$805,2015$.

FERREIRA, A. C. A sociedade de austeridade: poder, medo e direito do trabalho de exceção.

Revista Crítica de Ciências Sociais, Coimbra, v. 95, p. 119-136, 2011.

GALTUNG, J. Violence, peace, and peace research. Journal of Peace Research, London, v. 6, n. 3 , p. 167-191, 1969.

GALTUNG, J. Cultural violence. Journal of Peace Research, London, v. 27, n. 3, p. 291-305, 1990.

GOFFMAN, E. Stigma: notes on the management of spoiled identity. New York: Touchstone, 1963.

HARDING, G. Constructing addiction as a moral failing. Sociology of Health and Illness, Oxford, v. 8, n. 1, p. 75-85, 1986.

INCERTI, L.; HENDERSON-WILSON, C.; DUNN, M. Challenges in the family: problematic substance use and sibling relationships. Family Matters, Melbourne, v. 96, p. 29-38, 2015.

JACOBS, J. The feminization of alcohol use disorder and policy implications for women: "Sweet, pretty and pink". Gender and Behaviour, Johannesburg, v. 14, n. 1, p. 69oo-69o9, 2016.

JAQUIER, V.; FLANAGAN, J. C.; SULLIVAN, T. P. Anxiety and posttraumatic stress symptom pathways to substance use problems among community women experiencing intimate partner violence. Anxiety, Stress, and Coping, Oxford, v. 28 , n. 4 , p. $445-455,2015$.

KLEINMAN, A.; DAS, V.; LOCK, M. M. (Ed.). Social suffering. California: University of California Press, 1997.

LLOYD, C. The stigmatization of problem drug users: a narrative literature review. Drugs: Education, Prevention and Policy, Oxford, v. 20, n. 2, p. 85-95, 2013.

LYONS, T. Simultaneously treatable and punishable: implications of the production of addicted subjects in a drug treatment court. Addiction Research and Theory, Oxford, v. 22, n. 4, p. 286-293, 2014 .
ORFORD, J. How does the common core to the harm experienced by affected family members vary by relationship, social and cultural factors? Drugs: Education, Prevention and Policy, Oxford, v. 24, n. 1, p. 9-16, 2017.

ORFORD, J. et al. Methods of assessment for affected family members. Drugs: Education, Prevention and Policy, Oxford, v. 17, p. 75-85, 2012. Supplement 1.

PAULA, M. L. et al. Usuário de crack em situações de tratamento: experiências, significados e sentidos. Saúde e Sociedade, São Paulo, v. 23, n. 1, p. 118-130, 2014.

PORTUGAL. Lei $\mathrm{n}^{0}$ 30/200o, de 29 de novembro de 200o. Diário da República, Lisboa, n. 276, 29 nov. 200o. Série I-A.

PRENDERGAST, M. et al. Influence of perceived coercion and motivation on treatment completion and re-arrest among substance using offenders. Journal of Behavior and Health Services Research, London, v. 36, n. 2, p. 159176, 2009.

REIS, J. A anatomia da crise: identificar os problemas para construir alternativas. Apresentação do primeiro relatório preliminar do Observatório da Crise e Alternativas. Coimbra: CES, 2013.

RICHMAN, J. A. et al. Sexual harassment and generalized workplace abuse among university employees: prevalence and mental health correlates. American Journal of Public Health, Washington, DC, v. 89, n. 3,358-363, 1999.

RO, A.; CHOI, K. H. Effects of gender discrimination and reported stress on drug use among racially/ethnically diverse women in Northern California. Women's Health Issues, Toronto, v. 20, n. 3, p. 211-218, 2010.

RÜSCH, N.; ANGERMEYER, M.; CORRIGAN, P. Mental illness stigma: concepts, consequences, and initiatives to reduce stigma. European Psychiatry: The Journal of the Association of European Psychiatrists, Paris, v. 20, p. 52939, 2006. 
SLOBODA, Z.; GLANTZ, M. D.; TARTER, R. E.

Revisiting the concepts of risk and protective factors

for understanding the aetiology and development of substance use and substance use disorders: implications for prevention. Substance Use and Misuse, Oxford, v. 47, n. 8-9, p. 944-962, 2012.

SMITH, J. M.; ESTEFAN, A. Families parenting adolescents with substance abuse: recovering the mother's voice: a narrative literature review.
Journal of Family Nursing, Thousand Oaks, v. 20, n. 4, p. 415-441, 2014.

SOEIRO, J. Da Geração à Rasca ao Que se Lixe a Troika: Portugal no novo ciclo internacional de protesto. Sociologia, Lisboa, v. 28, p. 55-79, 2014.

UNODC - UNITED NATIONS OFFICE ON DRUGS AND CRIME. World drug report. Viena, 2016.

Disponível em: <https://bit.ly/28ThBYO>. Acesso em: 10 jun. 2017.

\section{Authors' Contribution}

Galvão was responsible for data collection and documental research. Saavedra and Cameira contributed with theoretical-methodological design. All the authors participated equally in the analysis of empirical data and in manuscript writing.

Received: 12/12/2017

Resubmitted: 08/05/2018

Approved: 15/05/2018 